\title{
Chapter 4 \\ Regulating Movement of the Very Mobile: Selected Legal and Policy Aspects of Ukrainian Migration to EU Countries
}

\author{
Monika Szulecka
}

\subsection{Introduction}

Analyzing the legal and policy aspects of the mobility of Ukrainian citizens requires clarification of what in fact influences this mobility in a legal and institutional sense. Primarily, it is migration policy, which may be understood as a state's system of regulations and practices towards foreigners as well as its own citizens leaving for other countries (potential and real migrants) together with its normative substantiation and executive institutions (see Lesińska et al. 2011). More specifically, immigration policy targeting incomers should be studied for the purposes of the analysis presented in this chapter, since the focus is on Ukrainian citizens coming to the European Union and to individual countries. Immigration policy is implemented through various kinds of policy instruments. Immigration law is regarded as the socalled "hard" policy instrument due to its binding nature and the consequences of law infringements. Besides regulations (such as employer sanctions or regularization programmes introduced by concrete laws), there are also "soft" policy instrument, such as guidelines or best practices to be followed. Currently immigration policies are based not only on control principles (although in the light of the

\footnotetext{
The original version of this chapter was revised. An erratum to this chapter can be found at DOI 10.1007/978-3-319-41776-9_14

The chapter is partly based on the draft text titled "Legal aspects of Ukrainian migration to the EU countries in the light of their changing migration policies and laws" prepared in 2014 by Michaela Maroufof, Marina Nikolova and Monika Szulecka as the input to the state of the art on Ukrainians' migration to the EU elaborated within IMISCOE research initiative.
}

M. Szulecka $(\bowtie)$

Centre of Migration Research, University of Warsaw, Warszawa, Poland

The Institute of Law Studies, The Polish Academy of Sciences, Warszawa, Poland

e-mail: m.szulecka@uw.edu.pl 
immigrant/asylum crisis of 2015 the main focus on control has been reinforced) aimed at governing the inflow and stay of foreigners, but also on integration principles, a direct result of the need to deal with ethnic diversity and provide support for migrants' adaptation in a growing number of states.

Importantly, the relation between migration policy and the law in force in a given state is not always concurrent. It may happen that the law in force has not been adjusted to take account of established policy goals, especially if they change relatively quickly. It is also possible that the state has almost no migration policy, which is more probable when cross-border mobility is not considered an issue in public debate. Then migration governance is usually limited to border control and establishing basic regulations regarding foreigners' stay in a given country (see e.g. Duszczyk 2012). Immigration policy and immigration regulations are interrelated and they change according to state goals and priorities linked to security and social cohesion on the one hand, and in response to labour market needs on the other.

In the EU context, however, we can describe immigration policies that are more or less developed depending on the immigration experience of a particular EU country, and EU migration policy, which is still being elaborated through, for instance, the passing of new directives to be implemented by EU states. Ukraine as an important source country of foreign labour force in a number of EU countries attracts special attention in the political debates on immigration to the EU. The geopolitical changes that have occurred in Europe over the last 25 years have been accompanied by the development of migration regulations at the EU level and in specific receiving nationstates, some of which directly affect the mobility of Ukrainians. Reports on immigration in the EU show that Ukrainian nationals are able to take advantage of regulations and policies potentially improving their administrative status (for instance, by applying for national visas that also give access to the labour market; see e.g. European Commission 2014). The particular strategies they adopt to cope with restrictions (including overstaying and waiting for regularization) depend on the nature of their migration and their economic goals (Gropas and Triandafyllidou 2014; Kraler et al. 2014). The strategies also depend on channels creating legal and institutional opportunity structures; in the EU this means migration and labour-market policies regarding third-country nationals who are citizens of its eastern neighbours.

Before the EU enlargement of 2004, Ukrainian nationals enjoyed a relatively liberal regime (with no visa requirement) crossing national borders to neighbouring countries, such as Poland, Hungary and Slovakia (previously also to Czechoslovakia). However, as EU candidates these countries were obliged to adapt their immigration regulations and border controls to the EU's requirements, which included the introduction of a visa requirement and restrictions on the conditions of foreigners' entry and stay. Although in some states (Poland and Hungary) these restrictions did not apply to the citizens of Ukraine until 2003, in Slovakia they were introduced as early as 2000 . 
Moreover, until implementation of the Schengen acquis in $2007-08^{1}$ by the new EU member states, ${ }^{2}$ the legal framework of Ukrainians' mobility between the home country and Poland, the Czech Republic, Slovakia and Hungary was quite liberal. Despite the introduction of obligatory visas, Poland's liberal policy toward the short-term mobility of Ukrainians and its tacit tolerance of often undocumented work performed by them represented a compromise between Poland's EU interests and its national interests in maintaining good relations with its eastern neighbour, a source country of significant migrant groups (see Kicinger 2005; Chap. 7).

Although new EU member states such as Poland and Hungary did not want to limit the entry of Ukrainian migrants and cross-border trade between Ukraine and their respective countries (especially Poland), meeting the EU's requirements inevitably meant strengthening the EU external border, and for Ukrainians, literally some closed gates. Hungary closed some of the small border crossing points between Hungary and Ukraine. For the Czech Republic, Poland, Slovakia and Hungary accession changed the status of Ukrainians to that of third-country nationals.

The tightened border controls and more restrictive policies might have been a barrier to spatial mobility for Ukrainians. However, the pull factors - the relatively attractive economic conditions in the Visegrad countries (V4: Czech Republic, Hungary, Poland and Slovakia) - were sufficiently strong to make them overcome the new and even more disadvantageous conditions, since these countries' membership of the Schengen Area was linked to further security improvements and restrictions in the visa regime (on economic pull factors for Ukrainian labour migrants, see Chap. 3). At the same time, however, the new EU member states were at least to some extent dependent on the workforce from Ukraine (Plewa 2007), leading to policy instruments that would satisfy the demand for foreign labour and maintain cross-border trade relations despite the restrictions on crossing borders and applying for permits to stay.

The EU's European Neighbourhood Policy led, for Ukraine, to the Eastern Partnership programme, which aimed to liberalize entry rules for citizens of EU neighbouring countries and prevent irregular migrants from developing countries in Asia and Africa from using Ukraine as the transit country to the EU. However, the political crisis of 2014-15 in Ukraine slowed the pace of activities aimed at waiving visa obligations for Ukrainian citizens. Some authors argue that Ukraine's participation in the Neighbourhood Policy has been motivated mostly by the desire of many Ukrainian citizens to guarantee a visa-free regime for Ukrainians travelling to the EU, with agreement on readmission requirements and improved border controls perceived as an acceptable price for this (see e.g. Düvell 2012; Düvell and Vollmer 2009).

Individual nation-states have taken specific steps, in accordance with EU structures as regards local border traffic, and independently in the case of regulations on the admission of foreigners to the EU labour markets - particularly in the case of the new member states. For instance, in Poland the law on foreigners' access to the

\footnotetext{
${ }^{1}$ Controls at internal land and sea borders were waived on 21 December 2007, and at internal air borders on 30 March 2008.

${ }^{2}$ The states that joined the EU in 2004.
} 
labour market has been significantly relaxed: the work permit application process has become cheaper and simpler, and citizens of selected countries, including Ukraine, have been allowed to work in Poland on a short-term basis without a work permit, provided that a special employer's declaration of intent to hire a foreigner has been registered. This regulation has made it easier to obtain a national visa giving the right to work in Poland (Duszczyk et al. 2010; see also Chap. 8).

Importantly, labour markets remain regulated mostly by national laws (see also Düvell 2011). There is practically no common EU policy for Ukrainian economic migrants and the observed trends are, at least to some extent, the result of policies and practices applied towards third-country nationals by particular countries, despite some accepted priorities (such as freedom of movement within EU territory, security of external borders and privileges for foreigners with certain skills). However, many changes in the national laws on access to residence permits and the labour market or restrictions in this area are the result of EU directives, such as the Single Permit Directive (2011/98/EU), the EU Blue Card Directive (Directive 2009/50/EC), the Researchers' Directive (2005/71/EC) or the directive on sanctions against employers of illegally staying third-country nationals (2009/52/EC) (see also Chap. 3).

This chapter discusses how legal and policy aspects of Ukrainians' migration in the EU context are reflected in the literature. Results of selected studies are presented with a particular focus on visa policies, special work programmes and regularization of migrants' stay. Migrants' legal status and experience of irregularity are also discussed.

\subsection{A Few Reflections on the Legal and Policy Context of Ukrainians' Movement in Migration Literature}

The legal and institutional context creating the opportunity for Ukrainians' migration does not usually constitute a separate research issue, mostly because legal or policy aspects are often described from a wider perspective, beyond that of a particular host or source country. This approach disguises the wide range of relations between mobility patterns of Ukrainians and general or specific policies at national or EU level.

Available literature often discusses migration of Ukrainian nationals in the context of the EU enlargements of 2004 (when Ukraine became a neighbour of the EU) and 2007. Since 2009, Ukraine's place in the Eastern Partnership programme within the European Neighbourhood Policy has been discussed in studies related to migration (Fargues 2013), although the programme is chiefly concerned with free-trade agreements (Dąbrowski and Maliszewska 2011).

Migration policy in practice is analyzed in the literature to emphasize that legal status results from both policies and their everyday implementation by the state, local authorities and individuals. Annual reports on migration prepared by, for instance, the European Commission, national contact points of the European Migration Network, the International Organization for Migration, the Organisation 
for Economic Cooperation and Development, FRONTEX and the Fundamental Rights Agency of the EU include data on how the legal framework influences migration flows and stocks (including irregularity), but they are generally based on statistics and short qualitative descriptions, and lack the detailed consideration of causes and consequences that is of interest to migration researchers (see e.g. FRONTEX 2015; ICMPD 2013). Comparative policy-oriented studies, such as those prepared annually by the European Migration Network, often omit the migrants' perspective, only providing information on particular migrant groups with regard to whom very specific programmes or policy tools are mentioned. National or local case studies on, for example, migrants' adaptation, mobility patterns and participation in the labour market provide some academic evidence of the role and implementation of migration regulations.

Ukrainians appear in wider categories of foreigners, such as third-country nationals in the EU context, citizens of ex-USSR countries or the CIS region, or nationals of countries participating in the Eastern Partnership programme, making it difficult to identify factors specific to them. Unsurprisingly, therefore, the literature mostly discusses those legal instruments or policies that are thought to have the greatest impact on Ukrainians' mobility patterns, including the visa facilitation process, regularization programmes and specific programmes admitting migrants from Ukraine to the labour markets. Most studies focus on admission policies and policy towards irregular migrants in a broad sense, since these are regarded as the most relevant for the context of Ukrainian nationals' mobility, and are important factors both increasing and decreasing migrant opportunities.

Literature on the legal aspects of Ukrainian mobility in the EU context can be divided into two main categories. First, there are comparative international studies that usually refer to specific issues, for example how regularization programmes or guarantees of fundamental rights shape patterns of mobility. Such studies refer to Ukrainian migrants only when they constitute a significant immigrant group to which particular legal instruments apply (e.g. Kupiszewski and Mattila 2008 with regard to policies controlling the legality of employment and addressing informal employment; FRA 2011 for the fundamental rights of irregular migrant domestic workers). The second category is represented by numerous case studies in which the legal status of Ukrainians functioning in particular $\mathrm{EU}^{3}$ states or even economic sectors is featured, but is not the main topic of analysis (e.g. Antoniewski 1997; Antoniewski and Koryś 2002; Drbohlav et al. 2008; Grzymała-Kazłowska et al. 2008; Hosnedlová and Stanek 2014; Näre 2011; Nikolova 2014).

A comparative study on the irregular employment of foreigners (Kupiszewski and Mattila 2008) considers why the informal employment of foreigners is common in some countries and what policies or lack of policies contribute to migrants' participation in the informal economy. In both Poland and Hungary undocumented work by Ukrainians was linked to the relatively easy access to those countries and

\footnotetext{
${ }^{3}$ Some case studies were also conducted in the pre-accession period of the 1990s or early 2000s in relation to the future EU-8 states, where immigration from Ukraine has always constituted a significant share of the migratory landscape.
} 
the low risk of detection that work performed during a "tourist" stay entailed. In Hungary cross-border trips by Ukrainians using visas allowing them to stay in Hungary for up to 90 days and work in the informal economy was usually arranged by ethnic Hungarians from Ukraine. For the border control authorities the real purpose of stay was irrelevant, since only the validity dates of visas were checked. Moreover, in Hungary the informal employment of foreigners was considered a marginal phenomenon in comparison to the informal employment of native Hungarians (Hars and Sik 2008). In Poland, informal work performed by Ukrainians was also linked to the structure and scale of the informal economy in general, with both Poles and foreigners working informally in agriculture or construction. Until 2007 the costly and time-consuming process of obtaining work permits for foreigners discouraged employers from hiring migrant workers legally. In 2007 the cost was reduced and access to all employment sectors without a work permit was introduced for seasonal workers from Belarus, Russia and Ukraine, which was supposed to decrease the scale of foreigners' presence in the informal economy (for more details see Chap. 7). However, according to this study the risk of detection of irregular employment remained very low, with the result that until Schengen enlargement easily obtainable tourist visas were used by Ukrainians to enter Poland and then work informally (Kicinger and Kloc-Nowak 2008).

A study by the EU's Fundamental Rights Agency (FRA 2011) investigated the fundamental rights of irregular migrant domestic workers. In some countries (especially Hungary and Poland) these were mostly Ukrainians working in private households who did not have valid documents authorizing them to stay in the country. Access to fundamental rights for migrants working irregularly is often at the discretion of their employers, and the study found that their main strategy in cases of sickness or exploitative practices was to change employer and to rely on social networks (for more details on the use of social networks by Ukrainian migrants in Poland see Chap. 7). Assistance from NGOs and trade unions was available in some sectors, but not for Ukrainians working in the domestic sector in Poland. Informal employment increases the risk of labour exploitation, bad working and living conditions, especially in agriculture and construction (Dąbrowski 2014; see also Chap. 3). Studies that include analysis of legal aspects of Ukrainian migration to the EU, along with economic, social or cultural factors, show a visible share of irregular migrants from Ukraine and - which is even more frequent - undocumented workers in many EU countries (including Poland, the Czech Republic, Greece, Italy and Portugal). According to Eurostat statistics, ${ }^{4}$ Ukrainian nationals are in the top ten countries of origin for measures targeting or preventing irregular migration and undocumented work by migrants in the EU. It is estimated that only about one-third of migrant workers from Ukraine in the EU have proper work and stay permits, while a quarter stay in the EU illegally (Coupé and Vakhitova 2013). This general picture of economic migrants from Ukraine in the EU is confirmed by studies conducted in particular countries (see Part II).

\footnotetext{
${ }^{4} \mathrm{http}$ ///ec.europa.eu/eurostat/statistics-explained/index.php/Statistics_on_enforcement_of_immigration_legislation. Accessed 10 Sep 2015.
} 


\subsection{Admitting Ukrainian Migrants to EU Territory and Labour Markets}

The broad concept of admission policies covers not only regulations and their implementation concerning entry to EU countries, but also laws referring to the labour market, since the two issues are inter-connected. The perspective applied in migration research usually considers how visa obligations limit migration of thirdcountry nationals and how facilitations may affect migration.

A study of Ukrainians in the Netherlands by Stepan Shakhno and Cathelijne Pool (2005) found that Ukrainian citizens were having increasing difficulty obtaining visas, as the authorities saw them as potential visa overstayers, and a growing number of visa applications were rejected, even though there had been no change in the visa regulations. This led to a sharp increase in the cost of arranging a visa, ${ }^{5}$ and to overstaying, as the higher the cost of the visa, the more time was needed to amass the funds to repay the costs. Moreover, leaving the destination country was linked to the risk of formal obstacles on re-entry into the Schengen Area. Restrictive visa policies were therefore thought to lead to an increase in non-compliant behaviour, including overstaying or the use of informal entry channels or papers.

Studies on EU migration from countries participating in the Eastern Partnership programme, which was initiated in 2009, have shown that visa-issuing practices vary across the member states, contrary to expectations under the EU Visa Code, which has been in force since 5 April 2010. A 2010 survey of visa applicants in Ukraine found that problems with the complexity of regulations, concerns over differing visa-issuing practices across the EU, lack of information and long visa application procedures discouraged them from following legal routes, turning instead to informal intermediaries, which usually meant higher costs (see Europe Without Barriers 2010). The risk of the undesirable development of informal services linked to visa-issuing processes means that visa facilitation agreements have grown in importance for both policy makers and researchers (Kahanec et al. 2013). Using informal channels to obtain a visa sometimes meant applying for visas that were not in fact linked to the real purpose of travel to EU countries. For instance, Polish national visas relatively easily obtained by nationals of Ukraine served for work not only in Poland, but also in other countries, such as Italy, Spain and the Czech Republic, although these visas did not allow paid activities to be performed in countries other than Poland.

It is important to emphasize that after the enlargement of the EU and the expansion of the Schengen Area, traditional destination countries for Ukrainian migrants, usually those bordering Ukraine, also introduced specific regulations providing exemption from EU-wide visa requirements, such as the agreements on local border traffic. In Poland, Hungary and Slovakia such agreements have been concluded (Fargues 2013), allowing citizens of Ukraine living in the border area (as defined by

\footnotetext{
${ }^{5}$ As individual applications were rejected, people determined to travel often had to arrange their visa through a travel agency, paying much more than the actual cost of the visa.
} 
these agreements) to enter the respective EU countries on the basis of multiple permits. However, this only applies to the areas immediately adjacent to the border on both sides, and leaving this border area without the appropriate documents, such as a visa or residence permit, is not permitted. Nonetheless, these local border traffic agreements have facilitated cross-border mobility of non-EU citizens, especially in the light of restricted visa policies stemming from EU and Schengen zone enlargement (for more information on the agreement on local border traffic between Poland and Ukraine see Chap. 7).

In a study of visa agreements between sending and receiving countries, Piotr Kaźmierkiewicz (research coordinator) (2009) examined the migration of Western Newly Independent States' (WNIS) citizens to Hungary, Latvia, Lithuania, Poland and the Slovak Republic. They suggested that before the integration of "new" EU member states into the Schengen zone, modified entry schemes ${ }^{6}$ had played a significant role in attracting migrants from the WNIS. Concrete steps have been taken by the receiving countries, including Poland, Slovakia and Hungary, to maintain such regimes. For instance, as announced by the Ukrainian Minister of Foreign Affairs, an agreement ${ }^{7}$ on the relaxation of mutual border crossing conditions for citizens of the Slovak Republic and Ukraine residing in the border zone was signed by the two countries in 2008, affecting 400,000 residents of 295 towns and villages. The aim of the agreement was to ease Ukrainian citizens' entry into the Slovak Republic by removing obstacles created after Slovakia's inclusion in the Schengen zone in December 2007 (Kaźmierkiewicz, research coordinator 2009). The effects of the local border traffic agreement between Ukraine and Poland that entered into force in 2009 (when Poland was already part of the Schengen zone) showed that it was treated more as a facility for frequent cross-border travellers than migrants. The frequent travellers were involved in trading in goods brought across the border (e.g. Konieczna-Sałamatin et al. 2012).

As the experience of the Slovak Republic shows, when the visa procedures for Ukrainians were liberalized and agreement on local border traffic was enforced, there was a reduction in the number of entry refusals of Ukrainian nationals (EMN Slovak Contact Point 2011). However, facilitating the obtaining of visas could also contribute to an increase in irregular migration. This is the case with Polish visas issued to Ukrainians declaring their entry purpose as seasonal work, business cooperation or private visits. Relatively easy access to supporting documents, especially to the declarations of intent to hire a foreigner registered by Polish employers, has turned Polish national visas into a very valuable asset for Ukrainians working (lawfully or unlawfully) in Poland or (usually unlawfully) in other EU countries, since

\footnotetext{
${ }^{6}$ Including visas free of charge (for instance tourist visas between Ukraine and Poland), local border traffic solutions applying to residents of border areas, and various exemptions from work permit requirements.

${ }^{7}$ The agreement introduced visa-free travel for a period up to 30 days for the residents of the $30-\mathrm{km}$-long border zone and a special permit allowing border-zone residents to stay in the border zone of the other country for a total of 90 days in a given 180-day period for social, cultural, economic and family reasons.
} 
it is much easier to gain entry visas to Poland than to other EU states (Klaus 2011; Bieniecki and Pawlak 2010; Duszczyk et al. 2010). The main aim of the declarations system was to enable migrants to function in the formal economy, cope with the restricted visa regime after Poland's accession to the Schengen Area and to solve the problems of labour shortages in some sectors. However, the system has often been abused by migrants seeking to enter the EU and earn more than they can in Poland (for more information see Chap. 7).

The liberalization of visa policies is in fact part of a broader programme of managing migration relations with countries neighbouring the EU. Marta Jaroszewicz (2012) traced the implementation of the Action Plan on Visa Liberalisation (VLAP), the ultimate goal of which is the lifting of visa requirements in the EU for, among others, nationals of Ukraine. The plan "includes conditions concerning document security (including biometrics), irregular immigration (including readmission), public order and security, external relations and fundamental rights" (Jaroszewicz 2012: 23). Several "new" EU member states (including Poland and Romania) have supported very strongly the introduction of a visa-free regime as it would "promote contacts between people and the development of democratic society" (Jaroszewicz 2012: 23) in the two countries. To a lesser degree, this was also supported by the foreign ministries of Sweden and Germany and by business circles in a number of EU member states, while Southern European countries remain relatively indifferent. However, most interior ministries of the "old" EU member states have been against abolition of visa requirements for Eastern European countries (Jaroszewicz 2012), mainly due to concerns about an increase in irregular migration and undeclared employment.

Interestingly, according to a study conducted in the Visegrad countries on prospects for mobility between these countries and Moldova, Belarus and Ukraine after the forthcoming visa abolition for travels up to 90 days (Jaroszewicz and Lesińska 2014), the removal of visa requirements is not expected to significantly increase the scale of Ukrainians' migration to the V4 countries. While there may be a modest increase in the number of economic migrants, family members and potentially also undocumented workers, the circularity and maybe also settlement rates may be higher due to continuing political unrest and the deteriorating economic situation in Ukraine related to military action in the east. The study also analyzed the political context of admitting Eastern Europeans to the Visegrad countries as the potential pull factor for migrants, including those from Ukraine. Jaroszewicz and Lesińska (2014) emphasize the diversity in policies towards labour migrants from the neighbouring countries of the EU: Hungary has been focused on admitting co-ethnics, and the Czech Republic revised its policies in the light of the economic crises and tightened up on the admission of foreigners to the labour market (with the exception of policies towards highly skilled migrants) (see also Chap. 8). Meanwhile, Poland's policy and regulations for admitting foreign labour have been liberalized to privilege nationals of the Eastern Partnership countries, with Ukrainians taking widespread advantage of this (see also Chap. 7).

There are special programmes aimed at admitting foreigners to the labour market, and, rarely, programmes based on bilateral agreements between Ukraine and the 
source country. For instance, in thematic studies on circular migration and the labour market in Portugal, a programme of this kind was cited as good practice satisfying the needs of the host country and improving the potential of the labour force in the country of origin. The main assumption of the programme was the return of seasonal Ukrainian workers recruited in Ukraine to their own country after completing assignments in Portugal (Aliens and Border Service 2010a, b; Chap. 11).

An example of policies that may result in improved access to both the territory and the labour markets of the receiving EU country is the policy towards co-ethnics, also called repatriation policy, introduced by Poland and Hungary. In both cases Ukraine was the source country of co-ethnics, who could gain some privileges in accessing long-term residence permits, access to the labour market and reduced fees for public transport or cultural institutions. In the case of Hungary it was the Hungarian Identity Card applied for by many Ukrainians living in the Ukrainian-Hungarian border areas. Holders of this card were mostly women working in Hungarian private households who wanted to maintain their ties with Ukraine. In the case of Poland it was the Polish Charter, whose beneficiaries have enjoyed easier access to entry visas, whether as employees or entrepreneurs, and to cultural events and free education (Lesińska et al. 2011). In Poland, the value of the Polish Charter increased after the Law on Aliens of 2013 came into force in May 2014: it facilitated access to permanent residence permits and citizenship for persons with documented Polish roots and holders of the Polish Charter (see more in Chap. 7).

\subsection{Regularization as a Long-Awaited Policy Tool}

The basic elements of migratory processes requiring regulation are: entry (prevention of illegal entry); stay (restrictions on the issue of residence permits, including permits issued to those previously illegally staying, and obligation to leave); and work (conditions of admission to the labour market and control of legality of employment). Regularization combines the priorities of policy on residence permits with those of policy towards irregular migrants. However, it is only one of the political reactions to irregular migration. Other elements include control policies (including rejecting entry or applications for residence permits or refusing permission to stay due to infringement of the conditions of stay), returns and readmission. Many studies on Ukrainians' adaptation to EU countries include the issue of migration and legalization strategies. In a number of states, especially in Southern Europe - in Italy, Greece, Spain and Portugal - waiting for regularization turned out to be one of the important elements of migrants' experiences (Ambrosini 2012; Kraler 2009; Kraler et al. 2014). Ukrainians are one of the nationalities to have benefited most from regularization programmes or mechanisms in a number of countries (e.g. in Portugal, Poland, Spain, Italy) and to have failed to do so due to the lack of regularization programmes in others (e.g. Czech Republic) (Baldwin-Edwards and Kraler 2009).

Studies in several EU countries (such as Spain, Portugal, Italy and Poland) show that migrants from Ukraine, like other third-country nationals, become irregular 
residents in particular by overstaying visas or temporary residence permits after entering EU territory legally (Vogel and Cyrus 2008; Kraler et al. 2014; Fonseca et al. 2014; Fagasiński et al. 2015). The 2015 migration crisis may change the trends that have been observed EU-wide for the last decade, but it should be emphasized that irregular entry during that period has mostly occurred through the southern borders of the EU, and, despite the political crisis in Ukraine, Ukrainian nationals do not constitute a significant share in the massive mobility of potential asylum seekers we observe on the EU territories today.

Studies of regularization provide information not only about the scale of previously irregular migrants from Ukraine in particular countries, but also the reasons for irregularity, the consequences of unregulated status and the potential changes that come with obtaining permits. Overstaying visas or residence permits is seen as a necessary, not the worst choice when the migration policy of the country includes regularization programmes from time to time (as in the case of Italy or Spain). Studies that provide not only statistical analysis of the programme's implementation, but also evidence from beneficiaries of regularization, may be a particularly valuable source of information about the long-term effects of regularization policies. Fagasiński et al. (2015) described the conditions in which Ukrainian migrants lived before they were granted residence permits (informal employment, low wages, risk of exploitation at work, lack of stability) and the advantages of being regularized most often a sense of security, stability and the opportunity to improve economic status. This study, however, also pointed out that the opportunities provided by regularization programmes may be "wasted" if migrants continue to experience problems having their work situation formalized (see also Reichel 2014). This highlights again the dependence of third-country nationals not only on migration regulations, but also on employment regimes, and their high level of dependency on their employers.

Between 1998 and 2007 five regularization programmes were introduced in Greece giving Ukrainians residing there the opportunity to regularize their stay. The majority of those who arrived with the first wave of immigration in the 1990s had decided to overstay and wait - up to 6 years in some cases - for the first regularization programme (Levchenko et al. 2010). This affected the duration of their stay in the country, as they could not travel freely back to Ukraine and then return to Greece. Those who entered between 2001 and 2005 were able to obtain stay and work permits quite quickly, as everyone was registered within less than a year of arrival (Levchenko et al. 2010). Those who arrived after 2005 had no chance to legalize their stay in such a framework, since there were no regularization programmes (see also Chap. 9).

In Portugal, the 2001 regularization legislation, which was in force for 18 months, was a pull factor in immigrants' choice of Portugal as destination country (Marques and Góis 2007). It also revealed the scale of the Ukrainian presence in the country as well as the role of networks in spreading the word about regularization. The middlemen in Ukraine widely promoted the regularization procedure and the job opportunities in the construction sector in Portugal. "It can be attributed to the marketing of Portugal done by Eastern European travel agencies, particularly in the Ukraine, that offered very attractive packages that included travel documents, 
transportation and job opportunities which were affordable to a large segment of the population" (Baganha et al. 2004: 31). Studies of regularization in Portugal show that in 2001, 63,000 immigrants from Ukraine received permits to stay. Importantly, the number of Ukrainians who regularized their stay was higher than that of traditional immigrant groups for Portugal, namely Brazilians and Cape Verdeans (Levinson 2005; Baldwin-Edwards and Kraler 2009, see also Chap. 11).

\subsection{Semi-compliance: The Predominant Status of Ukrainian Migrants?}

The commonly observed administrative status of Ukrainians in the EU is what is termed semi-compliance (see for example Kubal 2013; Ruhs and Anderson 2010), namely possessing valid documents authorizing stay, but doing undeclared work. This should be distinguished from non-compliance, where migrants have no authorization to stay, and thus work, in EU countries. The extent and character of irregularity by Ukrainian migrants in individual EU countries depends on admission regulations and policies towards irregular migration and the informal economy, as well as enforcement of the law. Undeclared work by Ukrainian migrants is often a complex issue, since it involves not only working without the required permit, but also abusing the channels that give access to the labour market (such as in Poland the system of declarations of intention to employ a foreigner, see also Chap. 7, and in the Czech Republic trade licences for hired workers - see Duszczyk et al. (2010); Leontiyeva (2014), for an analysis of the "Švarc system" in the Czech Republic see Chap. 8).

Why is Ukrainian migrants' legal status predominantly semi-compliant? There is a combination of factors: availability of legal channels in individual cases; migrants' economic aspirations; implementation of control policies in the host country; and existing tolerance towards informal employment. The stronger the push factors in Ukraine, the less important compliance with immigration rules may be for migrants who are willing to take risks in order to be able to work or live in other countries (Triandafyllidou 2013).

Geopolitical changes have to some extent "delegalized" mobility previously treated as "legal" in a visa-free regime (Haidinger 2007), although this often involves some form of non-compliance with the law, for instance, involvement in illegal trade (Iglicka 1999) or being employed without a proper work permit, but possessing an alternative proof of access to the economy (e.g. trade licence rather than work permit) in the destination country. Such practices are common among Ukrainian migrants in the Czech Republic (Drbohlav et al. 2008). It may be the case that undocumented work is neither the choice of the employee nor the employer when the government of the host country creates obstacles to discourage immigrants from applying for a stay permit, as in the case of Spain in 2004 (Markov 2009). 
As researchers have noted, as far as changes in administrative status are concerned, the greatest difference noticed by migrants is the shift from irregular to regular status, since it at least gives opportunities for lawful employment and cross-border travels. However, advancement in administrative status, meaning that migrants get long-term permits for stay and/or work or citizenship, does not necessarily lead to advancement in their economic status (Grzymała-Kazłowska et al. 2008; Kindler and Szulecka 2010; Stefańska and Szulecka 2013; Maroukis et al. 2011). Legal restrictions relating to the foreign labour force can make the lawful employment of foreigners unprofitable, costly or time-consuming.

Although Ukrainian migrants' legal status is one of the factors determining their opportunity structure, and influencing their adaptation strategies and the duration of their stay, these issues in turn impact their administrative status. The complex relationship between administrative status, possible irregularity linked to this status and other aspects of migrants' mobility and stay in the destination countries can be studied comparatively by looking at differences between Ukrainians and other national groups. For example, in Poland, Ukrainians are usually compared with Vietnamese, who constitute a significant migrant group although their numbers are lower. Both groups face general barriers to mobility, such as the need for visas and quite strict requirements for legalization of a long-term stay. However, although access to both the territory and the labour market is facilitated to some extent for Ukrainians, work in the informal sector is still very common among Ukrainian migrants. This stems from employers' reluctance to formalize the work relationship as well as economic calculations made by both migrants and employers. Unlike the Vietnamese (excluding those settled, with long-term residence permits), Ukrainians usually have valid documents authorizing them to stay in Poland, which are necessary if they are to be employed in accordance with the law (Stefańska and Szulecka 2013; Grzymała-Kazłowska et al. 2008; Górny et al. 2010).

A study on semi-compliance by Anderson et al. (2006) using interviews with nationals from EU-8 member states (including Poland and Lithuania) and from third countries (including Ukraine) showed that restricted access to the territory and the labour market in the UK in case of third-country nationals could contribute to migrants' vulnerability in the labour market. Some of them decided to use fake documents in order to get satisfactory jobs, but this still did not give them a sense of stability and security. As Anderson et al. (2006) argue, semi-compliant status should be recognized as an important issue not only by researchers, but also by policy makers.

Ukrainians' semi-compliant legal status has a number of consequences. Problems with semi-compliance are most often experienced by migrants at work: they may be unable to pursue their rights to work breaks, paid leave or proper pay rates (Klaus 2011; Skrivankova and Anti-Slavery International 2006). In some countries, such as the Czech Republic, semi-compliance stems from the way regulations on admitting foreigners to the labour market are applied. As Leontiyeva extensively describes in Chap. 8) and according to a study by Čermáková and Nekorjak (2009), Ukrainians 
constituted the group (after Vietnamese) at greatest risk of labour exploitation due to their isolation from the receiving society and the specific relations (client system) operating in their sectors, such as construction. However, despite problems linked to informal employment, Ukrainian migrants may gain some sense of security from networks and informal friendly relations with their employers (Harney 2012; Kindler and Szulecka 2013).

\subsection{Conclusions}

Although a good deal of information on the effects of policies is published in regular reports, more in-depth investigation of the legal framework from a critical perspective is needed. Several legal aspects of Ukrainian nationals' mobility are under-researched. First is the comparative study of changes in migrants' administrative status with a particular focus on Ukrainians, in the context of the enlarged European Union (after 2004) and Ukraine's cooperation with the EU on readmissions and visa system liberalization. A complex study covering the impact on migrants' trajectories of such factors as EU enlargement, Schengen zone enlargement and policy options in a number of countries hosting Ukrainians on a significant scale (Hungary, Czech Republic, Poland, Italy, Spain, Germany, Greece) would be valuable. It would update current knowledge and verify common assumptions, including those on the temporary character of Ukrainians' mobility and the prevalence of semi-compliant status among Ukrainians. Also relevant would be the consequences of the introduction of visas for Ukrainian migrants in various European countries, followed by the visa liberalization processes and the introduction of facilitations in entry policies targeting particular groups, including potential migrants (e.g. local border traffic, seasonal workers, highly skilled migrants). Such a study, which would require an interdisciplinary approach and intensive international cooperation based on empirical data, should be based not only on migrants' testimonies but also on information from other sources, such as institutional actors, employers and law enforcement agencies. National quantitative data to include areas outside the biggest cities would be effective in the analysis of mobility patterns in the context of changing regulations. In the light of upcoming visa abolition for Ukrainian citizens in the EU Visa Liberalisation Action Plan framework, it would also be challenging to study the prospects for the mobility of Ukrainians following this change of regime. So far, these have been studied in reference to, among others, Visegrad countries. Following up these studies after further steps in visa liberalization are undertaken could result in valuable knowledge on how changes in visa regime impact the mobility of Ukraine nationals, especially as regards the dominant economic character of this mobility.

Second, policies specific to Ukrainian nationals are not covered sufficiently in migration research. This is relevant, for instance, to highly qualified migrants finding employment other than in the secondary sectors usually associated with migrating Ukrainian nationals. Though relatively small, this group of migrants is worth 
studying from the legal perspective, in order to establish (i) whether there are obstacles that prevent well-qualified migrants from taking up jobs in the primary sector; (ii) whether discrimination occurs and whether there are any measures to prevent it; and (iii) whether there are any special schemes that would facilitate the migration of highly skilled migrants and how EU law (such as the EU Blue Card or the Researchers' Directive) has influenced their mobility and economic adaptation. The potential or real impact of these policies has been studied more broadly (Cerna 2008), without particular reference to Ukraine or without a particular focus on laws and policies (see Konieczna-Sałamatin (2015) on the phenomenon of migrants with diplomas in the Polish economy).

In many EU countries the law on migrants' access to the labour market and the regulations on prolonging legal stay have changed in the past decade. For instance, in Poland foreigners who have graduated from Polish universities since 2009 may work without a work permit and short-term workers may work on the basis of an employer's declaration of their intention to hire a foreigner. The Czech Republic offers privileged access to the labour market and the territory for highly skilled migrants and members of their families. There are many more examples of national regulations that can have an important influence on the mobility patterns of prospective and current Ukrainian migrants. The scale of the Ukrainian presence in many EU countries makes understanding of the outcomes of policies desirable for both academics and policy makers. Potential institutional and legal changes stemming from the immigrant/asylum crisis of 2015 are also of importance in the planning of studies. Although to a great extent these changes refer to the asylum system on national and EU levels, it is very probable that the crisis also impacts the legal framework on returns and the admission of third-country nationals. To what extent these changes may affect migration from Ukraine to the EU remains an open question.

Third, there is a continuing need for study of how the economic crisis, and the immigrant and asylum crisis, may result in migrants' position in the receiving economies deteriorating, causing them to lose their regular status when applying for documents becomes too costly. In receiving countries, deteriorating economic conditions are likely to lead to an increase in anti-immigrant sentiment (Awad 2009). Such a sentiment may also increase in the context of the immigrant/asylum crisis, although the cultural distance between the EU and sending regions (Eastern Europe, the Middle East and Northern Africa) as well as differing migration patterns may in fact cause the opposite effect, with Ukrainians more welcome than before, but incomers from outside Europe facing more restrictive policies. Among other factors, arrival patterns, the internal EU political crisis, racism, rising xenophobia and right-wing political populism need to be considered.

Increasing anti-immigrant sentiments may influence migration policies and their implementation, making migrants with an already precarious legal status as well as disadvantages in the labour market potentially even more vulnerable. However, in times of crisis special policies aimed at decreasing the negative effects of the downturn for immigrants may also be introduced, such as support to find a new job without losing their work permit if they become unemployed, or access to return 
programmes (see, for example, the policy choices made by the Czech Republic during the economic crisis; IOM 2010). The effects of the crisis may be felt in different ways at local level in different EU countries; for example, in Spain restrictions were introduced on access to health care, to which irregular migrants were previously entitled on registration at a local registration office (see Chap. 12).

Finally, in November 2013, the decision of the Ukrainian authorities not to sign the Association Agreement with the EU caused massive protests leading to larger revolutionary upheavals against the dictatorship of Ukrainian oligarchs, the corruption present at every level and the poor economic conditions in the country, which led to effective change of the country's leadership. The resultant political turmoil, linked with military action in the east of Ukraine and the annexation of the Crimea by Russia, induced greater caution on the EU's part, with Ukraine regarded as an unstable territory producing (so far unconfirmed) outflows of refugees and displaced people.

The Association Agreement, which was eventually signed in 2014, although not implemented till the end of 2015, paved the way for a visa-free regime (on fulfilment of a number of security conditions), which would allow Ukrainian migrants to avoid spending time and resources on visa applications and increase the protection of migrant workers' rights. Considering both the situation in Ukraine and the demand for foreign labour in many EU countries (where there is a preference for workers from the Eastern Partnership which includes Ukraine), it is clear that economic migration from Ukraine will not be decreasing in the near future, despite the slowness of the visa liberalization process.

However, both the political tensions and the military conflicts of 2014 and 2015 imply other possible scenarios for migration from Ukraine to the EU. The de facto independence of several of the eastern regions of Ukraine, especially in the Donbas region, raised the prospect of neighbouring EU countries - Poland, Hungary and the Slovak Republic - becoming a destination for Ukrainian asylum seekers fleeing from Eastern Ukraine and "Russian" Crimea (Leontiyeva 2014). This, in turn, raises questions about potentially more liberal practices within an even more restrictive legal framework toward third-country nationals and the recognition of Ukrainians fleeing the military conflict as deserving of international protection.

\section{References}

Aliens and Border Service. (2010a). Satisfying labour demand through migration in Portugal. European migration network. http://ec.europa.eu/dgs/home-affairs/what-we-do/networks/ european_migration_network/reports/docs/emn-studies/labour-demand/21a._portugal_ national_report_satisfying_labour_demand_thru_migration_version_5nov2010_en.pdf. Accessed 20 Sep 2015.

Aliens and Border Service. (2010b). Temporary and circular migration in Portugal: Facts, policies and strategies. European migration network. http://ec.europa.eu/dgs/home-affairs/what-wedo/networks/european_migration_network/reports/docs/emn-studies/circular-migration/21a. portugal_national_report_circular_migration_final_version_6_jan_2011_en.pdf. Accessed 20 Sep 2015. 
Ambrosini, M. (2012). Surviving underground: Irregular migrants, Italian families, invisible welfare. International Journal of Social Welfare, 21, 361-371. doi:10.1111/ j.1468-2397.2011.00837.x.

Anderson, B., Ruhs, M., Rogaly, B., \& Spencer, S. (2006). Fair Enough? Central and east European migrants in low-wage employment in the UK. Project Report. York: Joseph Rowntree Foundation.

Antoniewski, R. (1997). Przyczynek do badań nad nieformalnym rynkiem pracy cudzoziemców. Funkcjonowanie "giełdy pracy" w jednej z podwarszawskich miejscowości [Foreigners in the informal labour market. 'Labour stock market' in one of the towns near Warsaw]. CMR Working Papers (No 3). Warszawa: ISS UW. Available at: http://www.migracje.uw.edu.pl/ publ/549/. Accessed 8 Mar 2012.

Antoniewski, R., \& Koryś, I. (2002). Imigranci o nieuregulowanym statusie: społeczne i ekonomiczne determinanty funkcjonowania w Polsce [Irregular migrants: Socio-economic aspects of functioning in Poland]. CMR Working Papers (No 47). Warszawa: ISS UW.

Awad, I. (2009). The global economic crisis and migrant workers: Impact and response. Geneva: International Migration Programme, International Labour Organization.

Baganha, M.-I., Marques, J.-C., \& Góis, P. (2004). The unforeseen wave: Migration from Eastern Europe to Portugal. In M.-I. Baganha \& M.-L. Fonesca (Eds.), New waves: Migration from Eastern to Southern Europe (pp. 23-39). Lisbon: Luso-American Foundation.

Baldwin-Edwards, M., \& Kraler, A. (Eds.). (2009). REGINE: Regularisations in Europe. Study on practices in the area of regularisation of illegally staying third-country nationals in the member states of the EU. Appendix B: Country profiles of 22 EU member states and the USA. Vienna: ICMPD.

Bieniecki, M., \& Pawlak, M. (2010). Strategie ukraińskich migrantów zarobkowych wobec polskiej rzeczywistości instytucjonalnej [Strategies of Ukrainian economic migrants in Poland's instutional context]. Warszawa: ISP.

Čermáková, D., \& Nekorjak, M. (2009). Ukrainian middleman system of labour organization in the Czech Republic. Tijdschriftvooreconomische en sociale geografie, 100, 33-43. doi:10.1111/j.1467-9663.2009.00505.x.

Cerna, L. (2008). Towards an EU blue card: The proposed delegation of national immigration policies to the EU level. COMPAS Working Paper (pp. 08-65).

Coupé, T., \& Vakhitova, H. (2013). Costs and benefits of labour mobility between the EU and the eastern partnership partner countries - Country Report: Ukraine (September 2013). CASE Network Studies and Analyses No. 464. Available at: ssrn.com/abstract $=2323407$ or http:// dx.doi.org/10.2139/ssrn.2323407.

Dąbrowski, P. (2014). Praca przymusowa cudzoziemców w Polsce: analiza zjawiska w wybranych grupach imigranckich [Forced labour of foreigners in Poland: Analysis of the phenomenon among selected immigrant groups]. Warszawa: Wydawnictwa Uniwersytetu Warszawskiego.

Dabrowski, M., \& Maliszewska, M. (Eds.). (2011). EU eastern neighbourhood. Economic potential and future development. Berlin/Heidelberg: Springer.

Drbohlav, D., Dzúrová, D., Čermák, Z., Janská, E., Čermáková, D., \& Medova, L. (2008). Immigrants' irregular economic activities in the Czech Republic (a multi-approach study). European Review of Labour and Research, 14(4), 639-652.

Duszczyk, M. (2012). Polska polityka imigracyjna a rynek pracy [Polish immigration policy and the labour market]. Warszawa: O ficyna Wydawnicza ASPRA-JR.

Duszczyk, M., Lesińska M., Stefańska R., Szczepański, M., \& Szulecka, M. (2010). Polityka migracyjna w Polsce oraz jej wpływ na napływ i osiedlanie się imigrantów [Migration policy in Poland and its impact on the inflow and settlement of immigrants]. In A. Górny, I. GrabowskaLusińska, M. Lesińska, \& M. Okólski (Eds.), Transformacja nieoczywista. Polska jako kraj imigracji [Unobvious transformation. Poland as a country of immigration] (pp. 69-124). Warszawa: Wydawnictwa Uniwersytetu Warszawskiego.

Düvell, F. (2011). Paths into irregularity: The legal and political construction of irregular migration. European Journal of Migration and Law, 13(3), 275-295. 
Düvell, F. (2012). Transit migration: A blurred and politicised concept. Population Space and Place, 18, 415-427. doi:10.1002/psp.631.

Düvell, F., \& Vollmer, B. (2009). Irregular migration in and from the neighbourhood of the EU. A comparison of Morocco, Turkey and Ukraine. CLANDESTINO Report. Available at: http:// clandestino.eliamep.gr/wp-content/uploads/2009/10/transit_report_compas_sept09.pdf. Accessed 22 July 2012.

Europe Without Barriers. (2010). Schengen consulates in assessments and ratings visa practices of the EU member states in Ukraine 2010. Kiev. Available at: http://novisa.org.ua/wp-content/ uploads/2011/05/Viza_Monitor_ENG-3.pdf. Accessed 8 Mar 2013.

European Commission. (2014). 5th Annual report on immigration and asylum. Available at: http:// www.europarl.europa.eu/meetdocs/2014_2019/documents/com/com_com(2014)0288_/com_ com(2014)0288_en.pdf. Accessed 12 Oct 2015.

Fagasiński, M., Górczyńska, M., \& Szczepanik, M. (2015). Wychodzqc z cienia. Badanie prawnych, politycznych i spotecznych konsekwencji programu regularyzacyjnego [Coming out from the shadow. A study on the legal, political and social consequences of the regularisation programme]. Warszawa: Helsińska Fundacja Praw Człowieka.

Fargues, F. (Ed.). (2013). EU neighbourhood migration report 2013. Florence: European University Institute, Migration Policy Centre. Available at http://cadmus.eui.eu/bitstream/handle/1814/27394/MPC_NeighMigration.pdf?sequence=5. Accessed 20 Feb 2014.

Fonseca, M. L., Pereira, S., \& Esteves, A. (2014). Migration of Ukrainian nationals to Portugal: Changing flows and the critical role of social networks. Central and Eastern European Migration Review, 3(1), 115-130.

FRA. (2011). Migrants in an irregular situation employed in domestic work: Fundamental rights challenges for the European Union and its member states. Luxembourg: Publications Office of the European Union. http://fra.europa.eu/sites/default/files/migrants_in_an_irregular_situation_employed_in_domestic_work_en.pdf. Accessed 8 Mar 2013.

FRONTEX. (2015). Annual risk analysis. Available at: http://frontex.europa.eu/assets/Publications/ Risk_Analysis/Annual_Risk_Analysis_2015.pdf. Accessed 10 Oct 2015.

Górny, A., Grabowska-Lusińska, I., Lesińska, M., \& Okólski, M. (2010). Transformacja nieoczywista. Polska jako kraj imigracji [Unobvious tranformation. Poland as country of immigration]. Warszawa: Wydawnictwa Uniwersytetu Warszawskiego.

Gropas, R., \& Triandafyllidou, A. (2014). European immigration: A sourcebook. Aldershot: Ashgate Publishing.

Grzymała-Kazłowska, A., Stefańska, R., \& Szulecka, M. (2008). Różnice i podobieństwa w integracji migrantów o różnym statusie prawnym [Similarities and differences in integration of immigrants having different legal statuses]. In A. Grzymała-Kazłowska (Ed.), Między jednościq a wielością. Integracja odmiennych grup i kategorii migrantów w Polsce [Between unity and multiplicity. Integration of different groups and categories of immigrants in Poland] (pp. 81-140). Warszawa: OBM WNE UW.

Haidinger, B. (2007). Migration and irregular work in Europe. Literature review. Vienna. Available at: http://www.undocumentedmigrants.eu/londonmet/library/r81814_3.pdf. Accessed $20 \mathrm{Mar}$ 2014

Harney, N. D. (2012). Migrant strategies, informal economies and ontological security: Ukrainians in Naples, Italy. International Journal of Sociology and Social Policy, 32(1/2), 4-16.

Hars, A., \& Sik, E. (2008). Hungary - Towards balanced tightening of regulations on irregular employment. In M. Kupiszewski \& H. Mattila (Eds.), Addressing the irregular employment of immigrants in the European Union: Between sanctions and rights. Budapest: International Organization of Migration.

Hosnedlová, R., \& Stanek, M. (2014). Analysing selected transnational activities among Ukrainian immigrants in Spain. Central and Eastern European Migration Review, 3(1), 99-114.

ICMPD. (2013). Yearbook on illegal migration, human smuggling and trafficking in central and eastern Europe. A survey and analysis of border management and border apprehension data from 2010. With a special module on the detention of migrants and asylum seekers. Vienna: ICMPD. Available at: http://www.icmpd.org/fileadmin/ICMPD-Website/ICMPD_General/ Publications/2014/ICMPD_Yearbook2010_A5_final.pdf 
Iglicka, K. (1999). The economics of the petty trade on the eastern polish border. In K. Iglicka \& K. Sword (Eds.), The challenge of East-west migration for Poland (pp. 120-144). London: Macmillan.

IOM. (2010). Migration and the economic crisis in the European Union: Implications for policy. Brussels: IOM.

Jaroszewicz, M. (2012). Making the impossible possible. The prospects for visa-free movement between the EU and its eastern partners. Warsaw: OSW. Available at: http://www.osw.waw.pl/ sites/default/files/pw_27_en_0.pdf. Accessed 5 Oct 2015.

Jaroszewicz, M., \& Lesińska, M. (Eds.). (2014). Forecasting migration between the EU, V4 and eastern Europe. Impact of visa abolition. Warsaw: Ośrodek Studiów Wschodnich im. Marka Karpia.

Kahanec, M., Zimmerman, K.F., Kurekova, L., \& Biavaschi, C. (2013). Labour migration from EaP Countries to the EU - Assessment of costs and benefits and proposals for better labour market matching. IZA Research Report No. 56. Available at: http://www.iza.org/en/webcontent/publications/reports/report_pdfs/report_pdfs/iza_report_56.pdf. Accessed 20 Feb 2014.

Kaźmierkiewicz, P. (research coordinator). (2009). The situation of migrants from Belarus, Moldova and Ukraine on the labour markets of Latvia, Lithuania, Hungary, Poland and the Slovak Republic, Regional Report, Söderköping/Cross-Border Cooperation Process. Available at: http://www.unhcr.org/refworld/pdfid/4ed8edfa2.pdf. Accessed 10 May 2012.

Kicinger, A. (2005). Between polish interests and the EU influence - Polish migration policy development 1989-2004. CEFMR Working Paper, 9/2005. Available at: http://www.cefmr.pan.pl/ docs/cefmr_wp_2005-09.pdf. Accessed 5 Nov 2015.

Kicinger, A., \& Kloc-Nowak, W. (2008). Combating the illegal employment of foreigners in the enlarged European Union: Polish country report. In M. Kupiszewski, \& H. Mattila (Eds.), Addressing the irregular employment of immigrants in the European Union: Between sanctions and rights, IOM. Available at: http://www.cefmr.pan.pl/docs/cefmr_wp_2008-01.pdf. Accessed 10 May 2012.

Kindler, M., \& Szulecka, M. (2010). Integracja ekonomiczna migrantek na polskim rynku pracy przyczynek do badań. [Economic integration of women migrant on the Polish labour market a research case.] In M. Kindler, \& J. Napierała (Eds.), Migracje kobiet przypadek Polski. [Migration of women. Poland's case.] (pp. 138-160). Warszawa: Wydawnictwo Naukowe Scholar.

Kindler, M., \& Szulecka, M. (2013).The economic integration of Ukrainian and Vietnamese migrant women in the polish labour market. In L. Näre, \& J. Andall, (Eds.), Gender and the labour market in Europe. Journal of Ethnic and Migration Studies, 39, 649-667.

Klaus, W. (Ed.). (2011). Ziemia obiecana? Warunki pracy cudzoziemców w Polsce [Promised land? The conditions foreigners' work in Poland]. Warszawa: Stowarzyszenie Interwencji Prawnej.

Konieczna-Sałamatin, J. (Ed.). (2015). Imigranci o wysokich kwalifikacjach na polskim rynku pracy. Raport z badań 2014-2015 [Immigrants with higher qualifications on the Polish labour market, Report from the study of 2014-2015]. Warszawa: Instytut Społeczno-Ekonomicznych Ekspertyz.

Konieczna-Sałamatin, J., Świdrowska, E., \& Wołowski, P. (2012). Granica do naprawy. Problemy pogranicza Polski i Ukrainy [A border to be repaired. Problems of the Polish-Ukrainian borderland]. Warszawa: Fundacja im. Stefana Batorego. Available at: http://www.batory.org.pl/ upload/files/Programy\%20operacyjne/Otwarta\%20Europa/Granica_do_naprawy.pdf. Accessed 5 Oct 2015.

Kraler, A. (2009). Regularisation: A misguided option or part and parcel of a comprehensive policy response to irregular migration? IMISCOE Working Paper No 24.

Kraler, A., Reichel, D., König, A., Baldwin-Edwards, M., \& Şimşek, M. (2014). Final report Feasibility study on the labour market trajectories of regularised immigrants within the European Union (REGANE I). 
Kubal, A. (2013). Conceptualizing semi-legality in migration research. Law and Society Review, 47, 555-587. doi:10.1111/lasr.12031.

Kupiszewski, M., \& Mattila, H. (2008). Addressing the irregular employment of immigrants in the European Union: Between sanctions and rights. IOM. Available at: http://www.cefmr.pan.pl/ docs/cefmr_wp_2008-01.pdf. Accessed 10 May 2012.

Leontiyeva, Y. (2014). Ukrainian migration to Europe: Policies, practices and perspectives. Central and Eastern European Migration Review, 3(1), 5-10.

Lesińska, M., Stefańska, R., \& Szulecka, M. (2011). Development of migration policies of the Czech Republic, Hungary and Poland - on the way to maturity. In I. Grabowska-Lusińska, D. Drbohlav, \& A. Hars (Eds.), Immigration puzzles. Comparative analysis of the Czech Republic, Hungary and Poland before and after joining the EU (pp. 77-115). Saarbruecken: LAP LAMBERT Academic Publishing.

Levchenko, K., Malynovska, O., Shvab, I., \& Trofymenko, O. (2010).Ukrainian Greece: reasons, problems, prospects (According to the labour migrants' interview results), Institute of Sociology of the NAS of Ukraine and International Women's Rights Centre La Strada Ukraine.

Levinson, A. (2005). The regularisation of unauthorized migrants: Literature Survey and Country Case Studies. Regularisation programmes in Portugal. Oxford: Compas.

Markov, I. (2009). Ukrainian labour migration in Europe: Findings of the complex research of the processes of Ukrainian labour immigration. Lviv: Caritas Ukraine. Available at: http://www. kiev-dialogue.org/fileadmin/user_upload/KG_8_2012/0172_Markov_Caritas-1_01.pdf. Accessed 20 Feb 2014.

Maroukis, T., Iglicka, K., \& Gmaj, K. (2011). Irregular migration and informal economy in Southern and Central-Eastern Europe: Breaking the vicious cycle? International Migration, 49, 129-156. doi:10.1111/j.1468-2435.2011.00709.x.

Marques, J. C., \& Góis, P. (2007).Ukrainian migration to Portugal. From non-existence to one of the top three immigrant groups. Multicultural Centre Prague, migrationonline.cz.

Näre, L. (2011). The informal economy of paid domestic work: Ukrainian and polish migrants in Naples. In M. Bommes \& G. Sciortino (Eds.), Foggy social structures: Irregular migration, European labour markets and welfare state. Amsterdam: IMISCOE Research, Amsterdam University Press.

Nikolova, M. (2014). Ukrainian migration to Greece: patterns and challenges of remaining and of return. Central and Eastern European Migration Review (CEEMR), December 2014, 1-14. Available at: http://ceemr.uw.edu.pl/articles/ukrainian-migration-greece-patterns-and-challenges-remaining-and-return. Accessed 4 Feb 2015.

Plewa, P. (2007). The rise and fall of temporary foreign worker policies: Lessons for Poland. International Migration, 45, 3-36. doi:10.1111/j.1468-2435.2007.00402.x.

Reichel, D. (2014). 'This will benefit our society'. Regularisations and employment in Poland. REGANE assessment report. ICMPD: Vienna.

Ruhs, M., \& Anderson, B. (2010). Semi-compliance and illegality in migrant labour markets: An analysis of migrants, employers and the state in the UK. Population Space and Place, 16, 195-211. doi:10.1002/psp.588.

Shakhno, S., \& Pool, C. (2005). Reverse effects of restrictive immigration policy; Ukrainian migrants in the Netherlands. Available at: http://www.migrationonline.cz/e-library/?x=1963625. Accessed 4 Feb 2015.

Skrivankova, K., \& Anti-Slavery International. (2006). Trafficking for forced labour in Europe. Available at: http://www.antislavery.org/includes/documents/cm_docs/2009/t/trafficking_for_ fl_in_europe_4_country_report.pdf. Accessed 4 Feb 2015.

Stefańska, R., \& Szulecka, M. (2013). Bezpieczny status prawny jako determinanta awansu ekonomiczno-zawodowego odmiennych grup imigrantów w Polsce [Safe legal status as a factor of economic and professional advancement of different immigrant groups in Poland]. Central and Eastern European Migration Review, 2(1), 91-115. 
Triandafyllidou, A. (Ed.). (2013). Circular migration between Europe and its neighbourhood: Choice or necessity? Oxford: Oxford University Press.

Vogel, D., \& Cyrus, N. (2008). Irregular migration in Europe - Doubts about the effectiveness of control strategies. Focus migration policy brief No 9. Available at: http://focus-migration. hwwi.de/typo3_upload/groups/3/focus_Migration_Publikationen/Kurzdossiers/PB09Irregular-Migration.pdf. Accessed 23 Sep 2015.

Open Access This chapter is distributed under the terms of the Creative Commons AttributionNoncommercial 2.5 License (http://creativecommons.org/licenses/by-nc/2.5/) which permits any noncommercial use, distribution, and reproduction in any medium, provided the original author(s) and source are credited.

The images or other third party material in this chapter are included in the work's Creative Commons license, unless indicated otherwise in the credit line; if such material is not included in the work's Creative Commons license and the respective action is not permitted by statutory regulation, users will need to obtain permission from the license holder to duplicate, adapt or reproduce the material. 